S3 Fig. Format 3: Alternative package leaflet (intervention): Narrative with numbers (translation)

\title{
Side effects
}

Like all medicines, Suffia ${ }^{\circledR}$ can cause side effects. However, not all side effects are necessarily caused by the intake of Suffia ${ }^{\circledR}$. Symptoms can also occur when Suffia ${ }^{\circledR}$ is not taken.

\begin{tabular}{|c|c|}
\hline \multicolumn{2}{|c|}{ Symptoms occurring more often when taking Suffia ${ }^{\circledR}$ over 5 years: } \\
\hline $\begin{array}{l}\text { Increased blood sugar } \\
\text { levels }\end{array}$ & $\begin{array}{l}16 \text { of } 100 \text { people with } \text { Suffia }^{\circledR} \text { compared to } 13 \text { of } 100 \text { people without } \\
\text { Suffia }{ }^{\circledR} \text {. } \\
\text { In } 3 \text { of } 100 \text { people taking the drug Suffia }{ }^{\circledR} \text { is the increase of blood } \\
\text { sugar levels caused by the drug. }\end{array}$ \\
\hline Slow heart rate & $\begin{array}{l}5 \text { of } 100 \text { people with Suffia }{ }^{\circledR} \text { compared to } 2 \text { of } 100 \text { people without } \text { Suffia }{ }^{\circledR} \text {. } \\
\text { In } 3 \text { of } 100 \text { people taking the drug Suffia }{ }^{\circledR} \text { is the slow heart rate } \\
\text { caused by the drug. }\end{array}$ \\
\hline \multicolumn{2}{|c|}{ Symptoms occurring less often when taking Suffia ${ }^{\circledR}$ over 5 years: } \\
\hline Depression & $\begin{array}{l}9 \text { of } 100 \text { people with Suffia }{ }^{\circledR} \text { compared to } 12 \text { of } 100 \text { people without } \\
\text { Suffia }{ }^{\circledR} \text {. } \\
\text { In } 3 \text { of } 100 \text { people taking the drug Suffia }{ }^{\circledR} \text { is depression prevented by } \\
\text { the drug. }\end{array}$ \\
\hline \multicolumn{2}{|c|}{ Symptoms occurring with comparable frequency when taking or NOT-taking Suffia ${ }^{\circledR}$ over 5 years: } \\
\hline Anemia & 4 of 100 people in each case. \\
\hline
\end{tabular}

